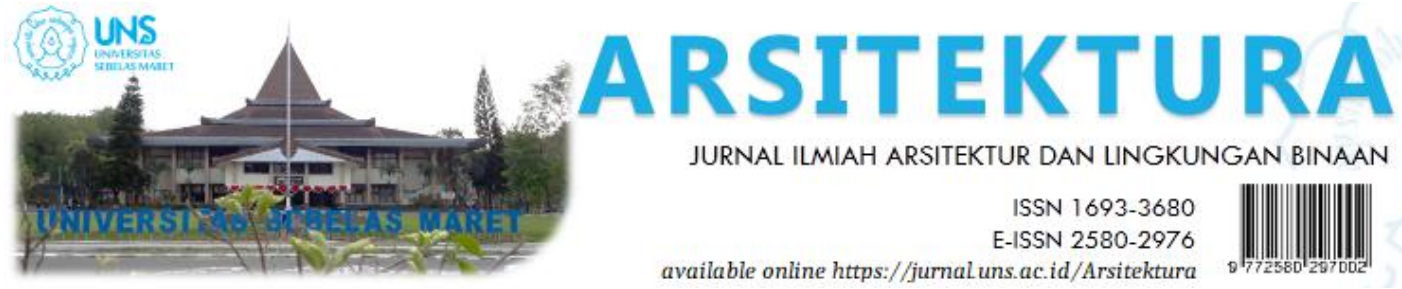

Volume 19 Issue 2 October 2021, pages:177-194

\title{
Preferensi Kenyamanan Pengunjung di Kebun Raya Bogor selama Adaptasi Kebiasaan Baru Berbasis Big Data
}

\section{Visitor Preference in Bogor Botanical Gardens During The New Normal Based On Big Data}

\author{
Yudith Vega Paramitadevi ${ }^{*}$, Nurul Jannah ${ }^{2}$, Gema Parasti Mindara ${ }^{3}$ \\ Program Studi Teknik dan Manajemen Lingkungan, Sekolah Vokasi Institut Pertanian Bogor ${ }^{1 *}$ \\ yudith.vega@apps.ipb.ac.id \\ Program Studi Teknik dan Manajemen Lingkungan, Sekolah Vokasi Institut Pertanian Bogor ${ }^{2}$ \\ Program Studi Manajemen Informatika, Sekolah Vokasi Institut Pertanian Bogor ${ }^{3}$
}

DOI: https://doi.org/10.20961/arst.v19i2.47627

Received: January 14,2021 Revised: June 04,2021 Accepted: June 22,2021 Available online: October 30,2021

\begin{abstract}
Urban communities need urban forests in improving the quality of mental and physical health during the New Normal. If ecotourism or urban forest is a top priority in implementing the New Normal, managers must determine designs, and make procedures related to the applicable COVID-19 protocol. The research objective was to measure the comfort level of visitors before and during the pandemic using big data, then compile comfort design recommendations according to visitor preferences during the pandemic based on survey methods. Social media Twitter and Google Map Review mentioning the Bogor Botanical Garden were collected a year before and six months during the pandemic. Analysis of text mining is carried out in order to obtain sentiment and initial perceptions about the Bogor Botanical Garden. Initial perceptions of visitors were used to construct the survey questionnaire. Furthermore, quantitative survey methods were used to analyze visitor activity and comfort. Visitor comfort is limited to abiotic factors, namely accessibility, and facilities. Sentiment analysis shows pre-pandemic conditions had $48.26 \%$ more positive word frequency than during the pandemic for Twitter, but 23.29\% less than during the pandemic for Google Map Review. Twitter are more sensitive to the current situation than Google Map Review. Positive perceptions of comfort include compliance management of KRB under the COVID-19 protocol (11.7\%), better management $(10.8 \%)$, well-maintained facilities and infrastructure (7.2\%), and maintained hygiene (7.2\%). Comfort design recommendations based on respondents' preferences for comfort $(14.4 \%)$ include increasing the number of toilets, the number of rest areas, ramps for the elderly, areas and attractions to attract children, parks with new themes, and sustainability elements.
\end{abstract}

Keywords: abiotic; big data; bogor botanical gardens; new normal; preference

\section{PENDAHULUAN}

Analisis big data selama ini digunakan dalam berbagai aspek, terutama kesehatan, sosial dan perbankan (Karamshuk et al., 2017; Stieglitz et al., 2018). Aspek big data untuk lingkungan hidup terutama desain pengelolaan hutan kota masih jarang penerapannya di Indonesia. Salah satu sumber data collection adalah data yang berasal dari sosial media, data tersebut berpotensi menyediakan pemahaman tentang tingkah laku dan persepsi masyarakat pada fasilitas umum (Hamstead et al., 2018; Zeng et al., 2017). Keunggulan data yang diperoleh dari 
sosial media antara lain tidak menimbulkan konflik kepentingan, volume data besar, data yang disediakan aktual. Pengguna sosial media mempublikasikan opini mereka melalui platform sosial media, maka datanya lebih representatif dibandingkan metode konvensional untuk memahami isu aktual dalam masyarakat (Tu et al., 2020).

Sosial media dapat menghasilkan data dalam jumlah besar, contohnya platform Twitter yang menghasilkan lebih kurang 473.400 cuitan per menit di seluruh dunia (Sim \& Miller, 2019). Sebagai informasi, peneliti sosial sudah menggunakan sosial media dalam penelitiannya, peneliti lingkungan masih sedikit yang menggunakan big data dalam analisisnya. Rata-rata peneliti lingkungan menggunakan analisis geospasial untuk mentransformasikan data lingkungan. Studi terkait sosial media di bidang pengelolaan hutan kota yang pernah dilakukan antara lain terkait dengan perencanaan taman kota (X. Chen et al., 2019) dan dinamika pengunjung di taman kota (Li et al., 2020). Kelemahan data yang berasal dari sosial media adalah perlu validasi dengan konteks penelitian yang dilakukan. Dengan demikian, perlu dilakukan silang uji dengan metode konvensional atau survei sesuai kebutuhan. Kelemahan pelaksanaan survei saja dalam penelitian adalah membutuhkan waktu dan tenaga dalam proses pengumpulan data termasuk subjektivitas peneliti (Y. Chen et al., 2018; Mahrous et al., 2018).

Adaptasi Kebiasaan Baru (selanjutnya disingkat menjadi AKB) merupakan masa relaksasi setelah Pembatasan Sosial Berskala Besar (selanjutnya disingkat menjadi PSBB). Hutan kota didesain untuk memenuhi kebutuhan masyarakat akan ruang terbuka hijau dan aktivitas rekreasional. Hutan kota Bogor atau Kebun Raya Bogor sendiri (selanjutnya disingkat menjadi KRB) terus berbenah selama AKB. KRB mengikuti kebijakan pemerintah berupa protokol pencegahan penularan corona virus disease (COVID-19) di tempat kerja sektor jasa dan perdagangan (area publik) dalam mendukung keberlangsungan usaha sesuai Keputusan Menteri Kesehatan Nomor HK.01.07/Menkes/382/2020 tentang Protokol Kesehatan Bagi Masyarakat di Tempat dan Fasilitas Umum dalam Rangka Pencegahan dan
Pengendalian Corona Virus Disease 2019 (COVID-19). Menurut Nordh \& Østby (2013) dan Peng et al. (2019), kenyamanan pengunjung hutan kota terbagi menjadi dua macam yakni kenyamanan biotik dan abiotik. Penelitian ini akan membahas kenyamanan abiotik yang meliputi aksesbilitas dan ketersediaan fasilitas.

Sebagai satu dari empat Kebun Raya dibawah Lembaga Ilmu Pengetahuan Indonesia (LIPI) dan PT Mitra Natura Raya, KRB memiliki pengunjung yang cukup signifikan tiap tahunnya dengan rerata $1-1.33$ juta jiwa. KRB tidak hanya dikenal di Indonesia dan Asia Tenggara namun didalamnya terdapat lebih dari 17.000 spesies pepohonan tropis, palem, anggrek dan lainnya (Hengky \& Kikvidze, 2018). KRB juga memiliki koleksi germplasm terlengkap di Asia Tenggara (Safarinanugraha, 2018). Data histori sosial media kurang lebih satu tahun terakhir dan kondisi saat pandemi menggunakan platform Twitter dan Google Map Review dapat digunakan untuk mengetahui aktivitas dan tingkat kenyamanan pengunjung. Koleksi big data tersebut kemudian diinterpretasikan sebagai masukan untuk membangun metode survei dalam rangka menyusun harapan pengunjung menuju AKB. Pada akhirnya, dua masukan tersebut dapat digunakan dalam mendesain KRB selama AKB sesuai pendapat pengunjung. Kajian desain dilakukan sesuai kriteria komponen abiotik. Tujuan penelitian antara lain mengukur tingkat kenyamanan pengunjung sebelum dan saat pandemi menggunakan big data, dan menyusun rekomendasi desain kenyamana pengunjung sesuai preferensi pengunjung selama AKB berdasarkan metode survei.

\section{METODE}

\subsection{Lokasi dan Waktu Penelitian}

Penelitian dilakukan di KRB. KRB merupakan salah satu kebun raya tertua di dunia dengan luasan $82 \mathrm{Ha}$, yang berdiri sejak tahun 1817 dan bertahan hingga saat ini. Letak KRB strategis di area JABODETABEK, area kewilayahan yang padat di dunia, dengan luasan $6392 \mathrm{~km}^{2}$ dan dihuni 20 juta jiwa, serta terkoneksi dengan JABODETABEK melalui jaringan jalan tol, jalan raya dan jalur kereta commuter. 
Data yang dikumpulkan dari sosial media berfungsi sebagai data historis. Postingan platform Twitter dan Google Map Review yang menyebutkan KRB digunakan sebagai data awal, dimana pengumpulan data tersebut dilakukan dalam periode sebelum pandemi (bulan Maret 2019-bulan Februari 2020) dan periode pandemi (bulan Maret 2020-Agustus 2020). Survei kuisioner untuk menunjang analisis sosial media dilakukan secara daring dengan target pengunjung tertentu pada minggu ke-3 dan minggu ke-4 bulan September setelah KRB dibuka per 7 Juli 2020.

\subsection{Metode Pengumpulan Data}

Data dikumpulkan secara sekunder dan primer. Berikut pengelompokan asal data:

\section{Data yang berasal dari sosial media}

Semua postingan yang menggunakan kata kunci KRB dicari melalui Twitter API dan Google Map Review. Dua sosial media tersebut dianalisis sekaligus sebagai perbandingan. Di Indonesia, data Twitter maupun Google Map Review lebih mudah diambil dibandingkan data sosial media lainnya. Setiap postingan yang mengandung kata kunci, "Kebun Raya Bogor" dan "Bogor Botanical Garden" diambil. Seluruh postingan dalam dataset berasal dari Indonesia.

2. Data yang berasal dari survei

Survei merupakan metode tradisional yang dapat digunakan untuk mengetahui harapan/ preferensi pengunjung pada AKB (Honey-Roses et al., 2020). Metode daring digunakan dalam survei dengan target pengunjung tertentu.

Data sekunder terakhir tahun 2019 menunjukkan rerata pengunjung perminggu sebesar 262 orang. Perhitungan dilakukan dengan rumus Slovin (Ryan, 2013), pengambilan sampel dilaksanakan dua minggu dengan margin of error 5\%, sehingga jumlah sampel adalah 234 orang.

Kuisioner dibagi menjadi lima bagian, yakni informasi responden, frekuensi kunjungan, aktivitas pengunjung, interaksi sosial pengunjung, preferensi/ harapan pengunjung terkait faktor abiotik. Pertanyaan-pertanyaan kuisioner secara spesifik berasal dari data histori hasil analisis sosial media. Demikian juga parameter yang digunakan untuk mengukur preferensi/ harapan pengunjung terkait faktor abiotik. Faktor abiotik yang dibahas terbatas pada ketersediaan sarana dan prasarana, pelayanan dan aksesbilitas menuju AKB. Skala likert digunakan untuk mengukur preferensi pengunjung dari nilai " 1 = Sangat Tidak Setuju" sampai nilai "5 = Sangat Setuju Sekali".

\subsection{Metode Analisis Data}

Data yang dianalisis adalah analisis sosial media dan analisis survei. Analisis sosial media menggunakan analisis text mining dan analisis sentimen, sedangkan bahasa $\mathrm{R}$ digunakan untuk analisis statistik berupa korelasi dan deskriptif. Desain tingkat kenyamanan pengunjung disusun sebagai rekomendasi setelah keterkaitan antar bagian dalam survei selesai dilakukan.

\section{Analisis data sosial media}

Analisis text mining terdiri dari tiga area: data mining, statistik dan linguistic, supaya diperoleh informasi penting dari data yang tidak terstruktur (Stieglitz et al., 2018). Pendekatan naïve bayes digunakan untuk menganalisis sentimen. Analisis sentimen tersebut berfungsi untuk menguraikan persepsi dan tingkah laku pengunjung (Grafius et al., 2019; Plunz et al., 2019), apabila nilai kelompok receiver operating characteristic (ROC) dalam rentang $80-90 \%$ maka klasifikasi yang dilakukan termasuk baik (Barca et al., 2020; Gorunescu, 2011). Analisis frekuensi digunakan untuk mengidentifikasi kata-kata utama dalam postingan sosial media. Analisis konten digunakan untuk mengkategorikan kata-kata utama ke dalam satu kata. Kategori tersebut dihitung untuk mengidentifikasi alasan sentimen dari pengunjung. Sentimen tersebut dapat menampilkan opini, sentimen, emosi dan tingkah laku (Sim $\&$ Miller, 2019). Melalui analisisanalisis tersebut, tingkat kenyamanan pengunjung sebelum dan saat pandemi dapat dijelaskan. 
2. Analisis data survei

Analisis data didesain untuk menjawab pertanyaan utama dalam penelitian ini: Apa sajakah preferensi pengunjung terhadap tingkat kenyamanan ditinjau dari faktor abiotik. Analisis dilakukan menggunakan bahasa pemrograman $\mathrm{R}$ Studio x64 4.0.3, yang diperoleh dari open source serta terintegrasi (IDE) dengan bahasa $\mathrm{R}$.

Pengklasifikasian data variabel menurut setiap kelompok yang awalnya belum teratur menjadi mudah disajikan secara informatif berdasarkan analisis deskriptif kuantitatif. Dengan demikian diperoleh karakteristik yang spesifik mengenai preferensi tingkat kenyamanan ditinjau dari faktor abiotik, dikorelasikan dengan informasi responden.

\section{HASIL DAN PEMBAHASAN}

\subsection{Hasil Analisis Sosial Media}

Sosial media yang dianalisis adalah Twitter dan Google Map Review. Kurun waktu pengambilan data Twitter melalui teknik data mining dibagi menjadi sebelum dan saat $\mathrm{AKB}$, diperoleh sebanyak 90 Tweets sebelum AKB dan 190 Tweets saat AKB. Jumlah Review terkait lokasi KRB di Google Map adalah \pm 3200 reviews, sebanyak 1991 review dengan sentiment negatif (1-2), 397 review netral (3) dan 879 review sentimen positif (4-5) berhasil diperoleh melalui data mining.

Tabel 1 merupakan perbandingan Twitter dan Google Map Review sebelum dan saat pandemi yang terbagi menjadi sentimen positif, netral dan negatif. Bag of lexicon yang digunakan untuk analisis Twitter disusun berdasar professional judgement sedangkan analisis Google Map Review menggunakan rating. Rating dalam Google Map Review tersebut mengacu pada penelitian sebelumnya (Y. Chen et al., 2018). Dua sosial media tersebut samasama dianalisis menggunakan menu stopword dan filtering pada tahap text preprocessing dalam R Studio, sehingga dapat mengurangi kata dan mengurangi perhitungan naïve bayes classifier. Hasil akhirnya hanya kata penting yang dihitung dan dapat meningkatkan akurasi.
Berdasarkan Tabel 2, hasil analisis sosial media menunjukkan model yang akurasinya $>80 \%$. Hasil ini sesuai dengan penelitian (Barca et al., 2020) bahwa analisis ROC naïve bayes akan akurat pada $80-90 \%$. Menurut (Sim \& Miller, 2019) sebagian besar analisis sosial media yang berhubungan dengan taman kota akan menghasilkan sentimen positif, hal yang sama juga berlaku dalam penelitian ini. Besaran sentimen positif sebelum maupun saat pandemi lebih tinggi 5.6 kali untuk analisis Twitter jika dibandingkan dengan sentimen negatif. Sentimen positif sebelum maupun saat pandemi lebih tinggi 5.3 kali untuk analisis Google Map Review jika dibandingkan sentimen negatif. Kondisi sebelum pandemi memiliki frekuensi kata positif lebih banyak $48.26 \%$ dibandingkan saat pandemi untuk Twitter, namun 23.29\% lebih sedikit dibandingkan saat pandemi untuk Google Map Review. Sementara kondisi saat pandemi memiliki frekuensi kata negatif lebih sedikit 54\% dibandingkan saat pandemi untuk Twitter dan lebih sedikit $86 \%$ dibandingkan saat pandemi untuk Google Map Review. Ulasan Twitter lebih sensitif menggambarkan perasaan pengguna dibandingkan review Google Map, hal ini sesuai dengan penelitian sebelumnya (Hamstead et al., 2018; Martí et al., 2019).

\subsection{Analisis Google Map Review}

Google Map Review dianalisis berdasarkan kondisi sebelum pandemi dan saat pandemi, dimana frekuensi kata negatif, netral dan positif diinterpretasikan sesuai dengan circlebar plot (Gambar 1). Kata positif sebelum pandemi dengan frekuensi tertinggi yaitu "jalan", "keluarga", "sejuk", "luas", "bagus", dan "nyaman". Pengunjung merasakan KRB adalah pilihan wisata untuk berjalan-jalan bersama keluarga karena sejuk, luas, bagus pemandangannya dan nyaman. Beberapa pengunjung mengunjungi KRB disertai alasan dekat dengan Istana Bogor. Kata "keliling", "hutan", "koleksi", "tumbuhan", "pohon", "mobil", dan "anak" dimaksudkan pengunjung mengelilingi KRB bersama anak menggunakan mobil untuk melihat hutan yang didalamnya terdapat koleksi pohon dan tumbuhan.

Sebelum pandemi frekuensi kata netral yang tertinggi adalah "mobil", "jalan", "bagus" dimana pengunjung menganggap akses jalan 
menuju KRB bagus karena dapat ditempuh dengan mobil. Ada juga kata "tiket", "terawat", "pohon", dan "nyaman", pengunjung menyatakan tiket masuk KRB digunakan agar pohon didalamnya terawat sehingga menimbulkan kenyamanan. Frekuensi kata negatif sebelum pandemi tertinggi yaitu "parkir", dimana pengunjung merasakan adanya ketidaknyamanan tempat, harga, dan kapasitas lahan parkir kendaraan. Kata "mobil" berkaitan erat dengan kemacetan, harga tiket, dan kepadatan kendaraan di dalam kebun raya. Pengunjung mengakui kebun raya "bagus" namun beberapa pengunjung menyayangkan manajemen pengelolaan KRB, terbatasnya fasilitas publik dalam KRB, dan harga makanan di dalam KRB yang dirasa mahal.

Gambar 1 juga menyebutkan sentimen positif, negatif dan netral saat pandemi. Kata negatif terkait kondisi saat pandemi dengan frekuensi tertinggi yaitu "mobil". Kata "mobil" berkaitan erat dengan kemacetan, harga tiket, dan lalulalang kendaraan di dalam kebun raya. Kata "sepeda" berkaitan dengan harga sewa sepeda yang termasuk mahal bagi sebagian pengunjung. Kata yang netral saat pandemi dengan frekuensi tertinggi antara lain "mobil", dimana pengunjung menganggap KRB dapat diakses dengan mobil. Kata-kata positif saat pandemi dengan frekuensi tertinggi yaitu "sejuk", "keluarga", "nyaman", dan "bagus". Ditinjau dari segi kenyamanan biotik, KRB termasuk area wisata yang sejuk untuk dinikmati bersama keluarga. Sedangkan menurut kenyamanan abiotik, KRB termasuk area wisata yang nyaman dengan pelayanan yang bagus. Pengelolaan KRB dari LIPI sudah diserahterimakan kepada PT Mitra Natura Raya sehingga profesionalisme layanan diperbaiki.

\subsection{Analisis Twitter}

Data Twitter yang diambil sebelum pandemi dilakukan pada kurun Maret 2019-Februari 2020 sehingga telah terdapat kata-kata "pandemi", "covid" dan "corona" (Gambar 2). Beberapa kata negatif tweet sebelum pandemi dengan frekuensi yang tinggi adalah "warga", "tolong", "tinggal", "sekitaran", "pikirkan", "mengamankan", "istana". Beberapa orang membuat tweet karena ingin meminta tolong kepada "istana" supaya mengamankan warga dengan cara mencegah penyebaran virus COVID-19.

Beberapa kata netral tweet sebelum pandemi dengan frekuensi yang tinggi adalah "bernyanyi", "suara", dan "serangga". Beberapa orang membuat tweet karena mendengar berbagai suara, baik dari serangga maupun orang bernyanyi. Kata lain yang muncul adalah "ditutup", "virus", "corona", "cegah", "penyebaran". Saat itu beberapa orang berharap agar KRB ditutup untuk mencegah penyebaran virus COVID-19. Kata positif tweet sebelum pandemi yang memiliki frekuensi tertinggi yaitu "corona", pengunjung perlu mengantisipasi penyebaran virus tersebut melalui penutupan kawasan wisata. Sebagai tambahan, wisata KRB dijadikan pilihan pengunjung karena memiliki daya tarik utama berupa koleksi bunga yang berada di hutan dan gardens.

Tweet negatif saat pandemi terjadi ketika beberapa orang menuliskan informasi mengenai pembukaan KRB kembali setelah beberapa saat tutup akibat pencegahan penyebaran COVID-19. Menurut (Martí et al., 2019; Sim \& Miller, 2019), analisis sentimen negatif di Twitter tidak mudah karena dibutuhkan minimal 20 kata yang disebutkan terus-menerus. Tweet kata yang negatif dalam penelitian ini belum tentu diartikan negatif karena hal tersebut. Kata netral tweet saat pandemi dengan frekuensi tertinggi adalah "covid", hal itu disebabkan adanya prediksi mengenai jumlah terkonfirmasi COVID-19 di bogor hingga ribuan orang, sehingga perlu diadakan pencegahan COVID-19. Tweet yang mengandung kata positif tertinggi saat pandemi yaitu "wisata", "covid", dan "hits". Beberapa orang membuat tweet tentang wisata di Bogor yakni KRB yang hits karena mirip dengan wisata di Eropa. Kemudian kata lain yang muncul adalah "gugus", "tugas", "corona", "new", dan "normal". Beberapa orang yang membuat tweet berharap semoga gugus tugas COVID-19 selalu diberi kesehatan pada masa AKB.

\subsection{Kategorisasi Kata untuk Penyusunan Kuisioner Survei}

Analisis sosial media menggunakan Twitter dan Google Map Review menghasilkan sentimen positif yang lebih banyak dibandingkan 
sentimen negatif dan netral. Kategorisasi kata dalam sosial media (Tabel 2) lebih menggambarkan interaksi sosial, kenyamanan abiotik, kepuasan terhadap layanan, isu terkini dan harapan saat AKB. Aktivitas pengunjung, keterkaitan antara kenyamanan dan kepuasan pengunjung tidak dapat digambarkan dengan baik melalui analisis sosial media. Hasil analisis terhadap Twitter lebih terkait dengan isu dan harapan terkini dibandingkan Google Map Review sehingga topik pencegahan dan penanganan COVID-19 mengemuka.

Kuisioner dalam penelitian ini disusun berdasarkan Tabel 2, tipe pertanyaan kuisioner tersebut adalah open-ended questions melalui daring yang disebarkan lewat sosial media dan grup komunikasi secara luas. Pertanyaan yang diberikan tidak terbatas pada Tabel 2 namun dikembangkan sesuai kebutuhan. Prosedur pencegahan COVID-19, aktivitas masyarakat di KRB selama AKB dan masukan serta saran dari responden ditambahkan dalam kuisioner tersebut.

\subsection{Hasil Analisis Kuisioner}

Survei lapangan yang dilakukan oleh Peneliti menunjukkan karakteristik pengunjung KRB. Sesuai dengan penelitian sebelumnya (Hengky \& Kikvidze, 2018), KRB dikunjungi mayoritas oleh wanita (53.4\%). Lebih kurang $81.62 \%$ pekerjaan pengisi survei adalah mahasiswa, diikuti oleh pelajar dan pengusaha. Meskipun kondisi $\mathrm{AKB}$, pengunjung yang mengisi survei berasal dari luar Kota Bogor (53.4\%) mendominasi (Tabel 3). Kuisioner penelitian ini ditujukan pada kelompok tertentu yakni pengguna media sosial Twitter, implikasinya pengisi kuisioner didominasi oleh pengunjung pada rentang usia 17-25 tahun (95.7\%). Target responden tertentu merupakan kelemahan dalam penelitian ini, disebabkan kuisioner yang dibagikan langsung pada pengunjung KRB berpotensi menimbulkan kerumunan.

Sejak dibuka pada 7 Juli 2020, KRB telah menerima pengunjung dengan memperhatikan protokol kesehatan COVID-19. Sebesar $42.31 \%$ responden telah berkunjung minimal satu kali selama AKB, sisanya belum berani mengunjungi KRB disebabkan berbagai hal. Salah satunya sosialisasi penerapan protokol kesehatan oleh KRB yang belum masif dilakukan di media massa, meskipun dalam website KRB (http://www.kebunraya.id) telah disebutkan prosedur kunjungan oleh pihak pengelola KRB.

Pengunjung memiliki alasan tersendiri dalam mengunjungi KRB selama masa AKB (Tabel 4). Aspek aktivitas fisik, kesehatan mental, interaksi sosial dan aspek lain merupakan tujuan warga mengunjungi taman kota (Nordh \& Østby, 2013; Razak et al., 2016). Upaya menenangkan hati dan pikiran $(33.5 \%)$ dan beristirahat $(21.9 \%)$ termasuk dalam upaya mempertahankan serta menjaga kesehatan mental. Seperti pendapat (Li et al., 2020; Sakip et al., 2015), aspek rekreasional mendominasi kunjungan warga perkotaan ke taman kota/ kebun raya. Aspek lainnya seperti keinginan untuk berinteraksi sosial (22.5\%) dan beraktivitas fisik (13.2\%) menempati urutan ke2 dan ke-3 selama AKB. Terjadi pergeseran tujuan pengunjung mendatangi taman kota/ kebun raya sebelum dan pada masa KRB. Sebelum AKB pengunjung memilih aktivitas fisik dan interaksi sosial sebagai tujuan utama, pada masa AKB pengunjung lebih mengutamakan aktivitas yang mendukung kesehatan mental.

Dalam menghadapi pandemi, KRB harus mempersiapkan berbagai hal diantaranya fasilitas yang memadai dan kepatuhan terhadap protokol yang dicanangkan oleh pemerintah. Pengunjung yang mendatangi KRB akan memperoleh kepuasan, keamanan dan kenyamanan dari upaya-upaya tersebut. Menurut (Febryano \& Rusita, 2018) pengunjung yang puas diperoleh dari kualitas kenyamanan yang mempengaruhi keinginannya untuk datang kembali. Penelitian (Widodo et al., 2018) menyatakan bahwa semakin tinggi tingkat pelayanan oleh pengelola maka semakin tinggi juga tingkat kepuasan yang diterima pengunjung dan stakeholder lainnya. Selain itu semakin baik fasilitas yang disediakan, akan mempengaruhi minat pengunjung untuk mendatangi KRB di masa selanjutnya. Bahasan kepuasan pengunjung dalam penelitian ini dilakukan terhadap penerapan protokol kesehatan di KRB, persepsi kenyamanan pengunjung dan berujung pada preferensi pengunjung terhadap fasilitas.

\subsection{Kepuasan Pengunjung terhadap Penerapan Protokol Kesehatan di KRB}


Pengelola KRB telah mengkomunikasikan standar layanan melalui website resminya, selain menerapkan protokol, membatasi pengunjung dan menyediakan fasilitas terkait pencegahan dan pengendalian COVID-19. Garis besar penerapan standar di KRB jika dibandingkan dengan peraturan yang berlaku yakni kurangnya frekuensi pengisian ulang cairan desinfektan, belum tersedianya tempat sampah khusus APD bekas pakai, jumlah tempat-tempat beristirahat yang kurang dan belum adanya prosedur pembatasan waktu bagi pengunjung berkelompok dan lansia.

Responden yang mengisi kuisioner menyatakan KRB patuh terhadap protokol kesehatan COVID-19 (mean $=4.05$ dari nilai maksimal 5.00), mereka menganggap perlu adanya pembatasan pengunjung di setiap area $($ mean $=$ 4.04 dari nilai maksimal 5.00). Fasilitas yang ada di KRB juga dianggap memadai selama masa AKB (mean $=3.88$ dari nilai maksimal 5.00), maka tak heran bahwa KRB merupakan wisata unggulan di masa AKB ini (mean $=3.89$ dari nilai maksimal 5.00). Peneliti lain (Bayuadi et al., 2020; Honey-Roses et al., 2020) juga menyatakan bahwa urban park adalah destinasi wisata bagi masyarakat sebagai bentuk pengalihan pikiran selama pandemi.

Keterkaitan antara kepatuhan KRB terhadap protokol kesehatan COVID-19, kebijakan pembatasan pengunjung dan fasilitas di KRB yang memadai selama masa AKB dianalisis menggunakan korelasi Spearman (Gambar 3). Hasil menunjukkan bahwa korelasi antara kepatuhan KRB terhadap protokol COVID-19 dengan kecukupan fasilitas sebesar 0.52 (nyata pada 0.01) yang artinya korelasi sedang, namun korelasi kepatuhan KRB terhadap protokol COVID-19 dengan pembatasan pengunjung sebesar 0.29 (nyata pada 0.01) yang artinya korelasi lemah dan positif. Ada keterkaitan antara kecukupan fasilitas dan pembatasan pengunjung, namun lemah dan positif (0.11) namun nyata pada taraf 0.1 . Terdapat beberapa penelitian mengenai kepatuhan obyek wisata terhadap protokol COVID-19 (Bayuadi et al., 2020; Honey-Roses et al., 2020), hanya jarang dijumpai penelitian yang menganalisis keterkaitan dengan aspek lainnya seperti kebijakan pembatasan pengunjung dan fasilitas memadai selama AKB.

\subsection{Persepsi Kenyamanan Pengunjung}

Pengunjung mengevaluasi kinerja layanan KRB setelah dibandingkan dengan harapan pengunjung dalam bentuk kepuasan yang terpenuhi saat berwisata di KRB, hasilnya didapatkan nilai 4.09 dari maksimal nilai 5.00. Sebelumnya pengelola KRB juga mengadakan survei kepuasan pengunjung di sepanjang 2019, diperoleh nilai 3.28 dari maksimal nilai 4.00. Berdasarkan dua hal tersebut pengunjung mendapatkan kepuasan dari berwisata di KRB, hal ini membuat pengunjung berkeinginan untuk kembali ke KRB di kemudian hari (mean $=4.27$ dari nilai maksimal 5.00). Daya tarik didalamnya bahkan menjadikan KRB merupakan obyek wisata untuk semua kalangan ( mean $=4.46$ dari total maksimal 5.00).

Korelasi antara kenyamanan pengunjung dengan kepuasan pengunjung dianalisis menggunakan Spearman dan diperoleh nilai 0.56 yang artinya korelasi sedang dan positif. Nilai 0.48 merupakan korelasi antara kenyamanan pengunjung dengan keinginan untuk kembali ke KRB, sedangkan korelasi antara kepuasan pengunjung dengan keinginan untuk kembali ke KRB diperoleh nilai 0.50. Keterkaitan antara tiga hal tersebut nyata pada taraf 0.01 (Gambar 4) sehingga kualitas layanan oleh pengelola KRB termasuk baik. Semakin tinggi kualitas layanan pengelola obyek wisata, kepuasan pengunjung semakin tinggi sehingga semakin besar pula minat wisatawan untuk kembali, hasil penelitian ini sejalan dengan penelitian (Nady, 2016; Razak et al., 2016).

\subsection{Preferensi Pengunjung terhadap Fasilitas}

Letak KRB yang berada di jantung kota Bogor dengan akses jalan yang beraspal, mudah dijangkau oleh kendaraan pribadi dan kendaraan umum, terdapat lebih dari dua pintu masuk mempermudah pengunjung untuk datang berkunjung. Meskipun pada AKB kebijakan PSBB diterapkan oleh Pemerintah Kota Bogor, tidak serta merta mempersulit pengunjung datang ke KRB. Lebih kurang setelah tanggal 7 Juli 2020 dibuka kembali, KRB telah didatangi 4645 pengunjung hingga akhir September 2020. Rerata hasil survei kuisioner juga menunjukkan nilai 3.85 dari nilai maksimum 5.00 yang menyatakan KRB mudah diakses. 
KRB memiliki lahan parkir serta fasilitas penunjang yang memadai serta aman bagi pengunjung (mean $=3.79$ dari nilai maksimum 5.00). Kebersihan dan keasrian KRB juga terjaga dengan baik menurut pengunjung (mean $=4.12$ dari nilai maksimum 5.00), pada akhirnya memunculkan rasa kenyamanan. Daya tarik titik tertentu dalam KRB seperti Museum Zoologi dan Istana Presiden Bogor menghasilkan mean 4.19 dari nilai maksimum 5.00, dua lokasi tersebut merupakan destinasi andalan di KRB. Faktor daya tarik pada spot tertentu dan faktor kebersihan merupakan hal kunci dalam menarik pengunjung ke KRB.

Preferensi pengunjung ditinjau dari persepsi kenyamanan abiotik berupa ketersediaan fasilitas diurutkan berdasarkan pendapat dan saran dari survei responden (Tabel 5). Persepsi kenyamanan positif terhadap faktor abiotik antara lain pengelolaan KRB sudah sesuai protokol COVID-19 (11.7\%), pengelolaan lebih baik daripada sebelumnya (10.8\%), sarana dan prasarana terawat $(7.2 \%)$, dan kebersihan terjaga (7.2\%). Adapun kepuasan pengunjung ditunjukkan dengan pendapat sangat bagus $(9.9 \%)$, menenangkan hati dan pikiran (6.3\%), dan pemandangan indah (4.5\%). Masukan ke depan antara lain perlu tambahan fasilitas (14.4\%), KRB harus tetap dilestarikan (4.5\%), harga tiket masuk lebih murah $(3.6 \%)$, sosialisasi lebih masif $(2.7 \%)$, dan perbaikan sarana yang rusak (1.8\%). Selanjutnya, terdapat pernyataan netral seperti edukasi dan koleksi flora (4.5\%), tempat wisata semua kalangan masyarakat (3.6\%), dan ikon kota Bogor yang dekat istana Bogor (3.6\%). Pernyataan negatif yang dapat ditingkatkan sebagai saran antara lain harga wahana keliling mahal (1.8\%) dan akses menuju KRB macet $(1.8 \%)$.

Masukkan ke depan dan pernyataan negatif dapat ditindaklanjuti sebagai rekomendasi desain kenyamanan berdasarkan faktor abiotik. Jenis tambahan fasilitas yang diperlukan berdasarkan masukan responden mayoritas (14.4\%) antara lain:

1. Jumlah toilet,

2. Jumlah tempat beristirahat,

3. Jalur ramps untuk lansia dan orangtua yang membawa baby stroller,
4. Area dan atraksi untuk menarik anakanak,

5. Taman dengan tema baru,

6. Spot air siap minum di beberapa titik.

Selain poin 1-6, terdapat masukan terkait sustainability element yakni composting area, rain and storm water harvesting, solar system sebagai lampu penerangan dan bangku ecofriendly. Kenyamanan pengunjung akan meningkatkan kepuasan pengunjung, kepuasan pengunjung berimbas pada pemenuhan KRB sebagai ruang terbuka hijau yang memenuhi unsur kesehatan masyarakat. Pelibatan masyarakat dalam penyusunan rekomendasi untuk perbaikan ruang terbuka hijau akan menumbuhkan rasa memiliki (Abdelhamid \& Elfakharany, 2020; Nordh \& Østby, 2013; Razak et al., 2016) sedangkan pertimbangan ekologis dengan memasukkan unsur sustainability akan menjaga KRB tetap lestari.

\section{KESIMPULAN}

Hasil analisis sosial media Twitter lebih mengemukakan isu pandemi dibandingkan media Google Map Reviews, keduanya samasama memiliki jumlah sentimen positif lebih banyak dibandingkan sentimen negatifnya. Hasil kategorisasi big data berbentuk analisis sosial media dapat menggambarkan interaksi sosial, kenyamanan abiotik, kepuasan terhadap layanan dan isu terkini serta harapan saat AKB. Hal yang kurang dapat digambarkan melalui analisis sosial media adalah jenis-jenis aktivitas pengunjung dan korelasi antara kenyamanan dan kepuasan pengunjung.

Berdasarkan hasil survei pengunjung yang didominasi oleh warga di luar kota Bogor, terjadi pergeseran tujuan pengunjung mendatangi kebun raya selama masa AKB. Sebelum AKB pengunjung memilih aktifitas fisik dan interaksi sosial sebagai tujuan utama, pada masa AKB pengunjung lebih mengutamakan aktivitas yang mendukung kesehatan mental. Bahasan kepuasan pengunjung dalam penelitian ini dilakukan terhadap penerapan protokol kesehatan di KRB, persepsi kenyamanan pengunjung dan berakhir pada preferensi pengunjung terhadap fasilitas. Fasilitas pencegahan dan penanganan COVID19 di KRB sudah memadai, meskipun masih terdapat hal-hal yang masih belum standar 
menurut pengamatan lapang. Kondisi tersebut didukung hasil kuisioner berupa korelasi positif dan sedang antara kepatuhan KRB terhadap protokol COVID-19 dengan ketercukupan fasilitas. Pengunjung menganggap KRB nyaman, pelayanannya baik sehingga mereka akan kembali berkunjung ke KRB. Fasilitas berupa spot tertentu dan kebersihan yang terjaga merupakan hal kunci dalam menarik pengunjung. Fasilitas yang perlu ditambahkan menurut preferensi pengunjung antara lain jumlah toilet, tempat beristirahat, jalur ramps untuk lansia, area dan atraksi menarik untuk anak-anak, taman dengan tema baru serta sustainability elements.

Kajian mengenai penggunaan sosial media dalam bidang lanskap dan lingkungan dapat dijadikan pertimbangan sebelum melakukan survei konvensional dalam rangka perbaikan fasilitas untuk kenyamanan pengunjung di masa AKB. Penelitian ini memiliki kekurangan yakni diperuntukkan bagi target pengunjung tertentu dan belum mempertimbangkan keterbatasan finansial KRB dalam perencanaan desainnya. Hal positif sebagai temuan yang diidentifikasi adalah pengunjung tetap menginginkan pengelola KRB memberikan pelayanan terbaik, demi kesehatan mental serta raga mereka selama $\mathrm{AKB}$.

\section{UCAPAN TERIMA KASIH}

Penelitian ini dibiayai oleh skema Hibah Bersaing Penelitian di Sekolah Vokasi IPB dengan nomor surat perjanjian penugasan: 10165/IT3.S3/KS/2020. Ucapan terimakasih diberikan kepada Wakil Dekan Bidang Sumberdaya, Kerjasama dan Pengembangan di Sekolah Vokasi IPB serta kepada PT Mitra Natura Raya sebagai pengelola Kebun Raya Bogor.

\section{DAFTAR PUSTAKA}

Abdelhamid, M. M., \& Elfakharany, M. M. (2020). Improving urban park usability in developing countries : Case study of AlShalalat Park in Alexandria. Alexandria Engineering Journal, 59(1), 311-321. https://doi.org/10.1016/j.aej.2019.12.042.

Barca, E., Castrignanò, A., Ruggieri, S., \& Rinaldi, M. (2020). A new supervised classifier exploiting spectral-spatial information in the Bayesian framework. International Journal of Applied Earth Observation and Geoinformation, 86(October 2019), 101990. https://doi.org/10.1016/j.jag.2019.101990

Bayuadi, M. W., Sudarwanto, B., \& Pandelaki, E. E. (2020). Pengembangan Taman Kota dengan Outdoor Coworking Space Pasca Pandemi Covid-19 City Parks Development by means of Outdoor Coworking Space after the Covid-19 Pandemic. 18(2), 303-314.

Chen, X., de Vries, S., Assmuth, T., Dick, J., Hermans, T., Hertel, O., Jensen, A., Jones, L., Kabisch, S., Lanki, T., Lehmann, I., Maskell, L., Norton, L., \& Reis, S. (2019). Research challenges for cultural ecosystem services and public health in (peri-)urban environments. Science of the Total Environment, 651, 2118-2129. https://doi.org/10.1016/j.scitotenv.2018.0 9.030.

Chen, Y., Liu, X., Gao, W., Wang, R. Y., Li, Y., \& Tu, W. (2018). Emerging social media data on measuring urban park use. Urban Forestry and Urban Greening, 31(November 2017), 130-141. https://doi.org/10.1016/j.ufug.2018.02.00 5.

Febryano, I. G., \& Rusita. (2018). Persepsi Wisatawan Dalam Pengembangan Wisata Pendidikan Berbasis Konservasi Gajah Sumatera (Elephas maximus sumatranus) Perception of Tourist Development Based Tourism Conservation Education of Sumatran. Jurnal Pengelolaan Sumberdaya Alam Dan Lingkungan, 8(3), 376-382.

https://doi.org/10.29244/jpsl.8.3.376-382.

Gorunescu, F. (2011). Data mining: Concepts, models and techniques. In Prof. Lakhmi C. Jain; Prof. Janusz Kacprzyk (Ed.), Intelligent Systems Reference Library (Intelligen, Vol. 12, Issue 2). SpringerVerlag Berlin Heidelberg. https://doi.org/10.1007/978-3-64219721-5.

Grafius, D. R., Corstanje, R., Warren, P. H., Evans, K. L., Norton, B. A., Siriwardena, G. M., Pescott, O. L., Plummer, K. E., Mears, M., Zawadzka, J., Richards, J. P., \& Harris, J. A. (2019). Using GIS-linked 
Bayesian Belief Networks as a tool for modelling urban biodiversity. Landscape and Urban Planning, 189(August 2018), 382-395.

https://doi.org/10.1016/j.landurbplan.201 9.05.012.

Hamstead, Z. A., Fisher, D., Ilieva, R. T., Wood, S. A., McPhearson, T., \& Kremer, P. (2018). Geolocated social media as a rapid indicator of park visitation and equitable park access. Computers, Environment and Urban Systems, 72(January), 38-50. https://doi.org/10.1016/j.compenvurbsys. 2018.01.007.

Hengky, S. H., \& Kikvidze, Z. (2018). Tourism sustainability in the Bogor Botanical Gardens, Indonesia. Urban Forestry and Urban Greening, 30(January), 8-11. https://doi.org/10.1016/j.ufug.2018.01.00 7.

Honey-Roses, J., Anguelovski, I., Bohigas, J., Chireh, V., Daher, C., Konijnendijk, C., Litt, J., Mawani, V., McCall, M., Orellana, A., Oscilowicz, E., Sánchez, U., Senbel, M., Tan, X., Villagomez, E., Zapata, O., \& Nieuwenhuijsen, M. (2020). The Impact of COVID-19 on Public Space: A Review of the Emerging Questions. 1-20. https://doi.org/10.31219/osf.io/rf7xa.

Karamshuk, D., Shaw, F., Brownlie, J., \& Sastry, N. (2017). Bridging big data and qualitative methods in the social sciences: A case study of Twitter responses to high profile deaths by suicide. Online Social Networks and Media, 1, 33-43. https://doi.org/10.1016/j.osnem.2017.01. 002.

Li, F., Li, F., Li, S., \& Long, Y. (2020). Deciphering the recreational use of urban parks: Experiments using multi-source big data for all Chinese cities. Science of the Total Environment, 701, 134896. https://doi.org/10.1016/j.scitotenv.2019.1 34896.

Mahrous, A. M., Moustafa, Y. M., \& Abou ElEla, M. A. (2018). Physical characteristics and perceived security in urban parks: Investigation in the Egyptian context. Ain Shams Engineering Journal, 9(4), 30553066.

https://doi.org/10.1016/j.asej.2018.07.00
3.

Martí, P., Serrano-Estrada, L., \& NolascoCirugeda, A. (2019). Social Media data: Challenges, opportunities and limitations in urban studies. Computers, Environment and Urban Systems, 74(May 2018), 161174.

https://doi.org/10.1016/j.compenvurbsys. 2018.11.001.

Nady, R. (2016). Towards Effective and Sustainable Urban Parks in Alexandria. Procedia Environmental Sciences, 34, 474-489.

https://doi.org/10.1016/j.proenv.2016.04. 042.

Nordh, H., \& Østby, K. (2013). Pocket parks for people - A study of park design and use. Urban Forestry and Urban Greening, 12(1), $12-17$. https://doi.org/10.1016/j.ufug.2012.11.00 3.

Peng, Y., Feng, T., \& Timmermans, H. (2019). A path analysis of outdoor comfort in urban public spaces. Building and Environment, 148(November 2018), 459467.

https://doi.org/10.1016/j.buildenv.2018.1 1.023.

Plunz, R. A., Zhou, Y., Carrasco Vintimilla, M. I., Mckeown, K., Yu, T., Uguccioni, L., \& Sutto, M. P. (2019). Twitter sentiment in New York City parks as measure of wellbeing. Landscape and Urban Planning, 189(April), 235-246. https://doi.org/10.1016/j.landurbplan.201 9.04.024.

Razak, M. A. W. A., Othman, N., \& Nazir, N. N. M. (2016). Connecting People with Nature: Urban Park and Human Wellbeing. Procedia - Social and Behavioral Sciences, 222, 476-484. https://doi.org/10.1016/j.sbspro.2016.05. 138.

Ryan, T. P. (2013). Sample Size Determination and Power (G. M. F. David J. Balding, Noel A. C. Cressie, D. W. S. Harvey Goldstein, Iain M. Johnstone, Geert Molenberghs, S. W. Adrian F. M. Smith, Ruey S. Tsay, \& J. L. T. Editors Emeriti: Vic Barnett, J. Stuart Hunter, Joseph B. Kadane (eds.); Wiley Seri). John Wiley \& Sons.

Safarinanugraha, D. (2018). Perkembangan 
Desain Kebun Raya Bogor Tahun 18172017 Berbasis Aspek Spasial dan Fungsional. In Sekolah Pascasarjana Institut Pertanian Bogor. Institut Pertanian Bogor.

Sakip, S. R. M., Akhir, N. M., \& Omar, S. S. (2015). Determinant Factors of Successful Public Parks in Malaysia. Procedia Social and Behavioral Sciences, 170, 422-432.

https://doi.org/10.1016/j.sbspro.2015.01. 003.

Sim, J., \& Miller, P. (2019). Understanding an urban park through big data. International Journal of Environmental Research and Public Health, 16(20). https://doi.org/10.3390/ijerph16203816.

Stieglitz, S., Mirbabaie, M., Ross, B., \& Neuberger, C. (2018). Social media analytics - Challenges in topic discovery, data collection, and data preparation. International Journal of Information Management, 39(October 2017), 156168.

https://doi.org/10.1016/j.ijinfomgt.2017.1 2.002.

Tu, W., Zhu, T., Xia, J., Zhou, Y., Lai, Y., Jiang, J., \& Li, Q. (2020). Portraying the spatial dynamics of urban vibrancy using multisource urban big data. Computers, Environment and Urban Systems, 80(October), 101428. https://doi.org/10.1016/j.compenvurbsys. 2019.101428.

Turan, S. Ö., Pulatkan, M., Beyazlı, D., \& Özen, B. S. (2016). User Evaluation of the Urban Park Design Implementation with Participatory Approach Process. Procedia - Social and Behavioral Sciences, 216(October 2015), 306-315. https://doi.org/10.1016/j.sbspro.2015.12. 042.

Widodo, M. L., Soekmadi, R., \& Arifin, H. S. (2018). Analisis Stakeholders Dalam Pengembangan Ekowisata Di Taman Nasional Betung Kerihun Kabupaten Kapuas Hulu. Jurnal Pengelolaan Sumberdaya Alam Dan Lingkungan, 8(1), 55-61.

https://doi.org/10.29244/jpsl.8.1.55-61.

Zeng, C., Yang, L., \& Dong, J. (2017). Management of urban land expansion in China through intensity assessment: A big data perspective. Journal of Cleaner

Production, 153, 637-647. https://doi.org/10.1016/j.jclepro.2016.11. 090. 


\section{Lampiran}

Tabel 1. Perbandingan analisis Twitter dan Google Map Review

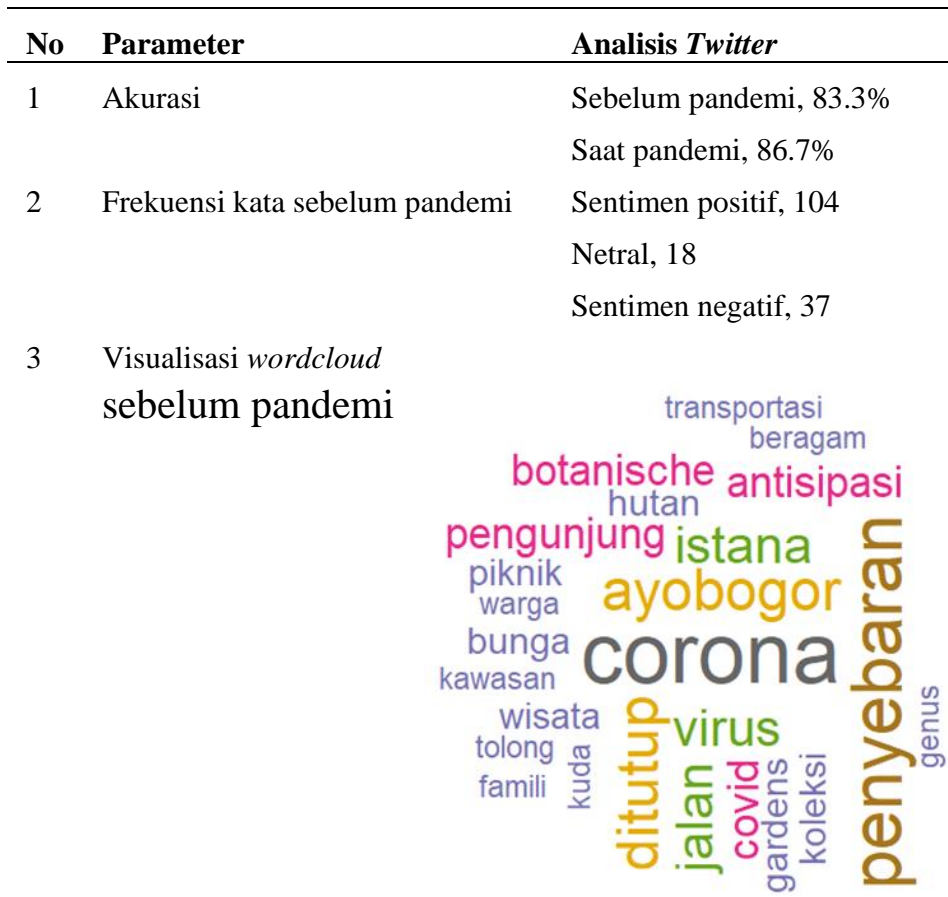

Analisis Google Map Review

Sebelum pandemi, $96.5 \%$

Saat pandemi, $84.1 \%$

Sentimen positif, 1482

Netral, 791

Sentimen negatif, 444

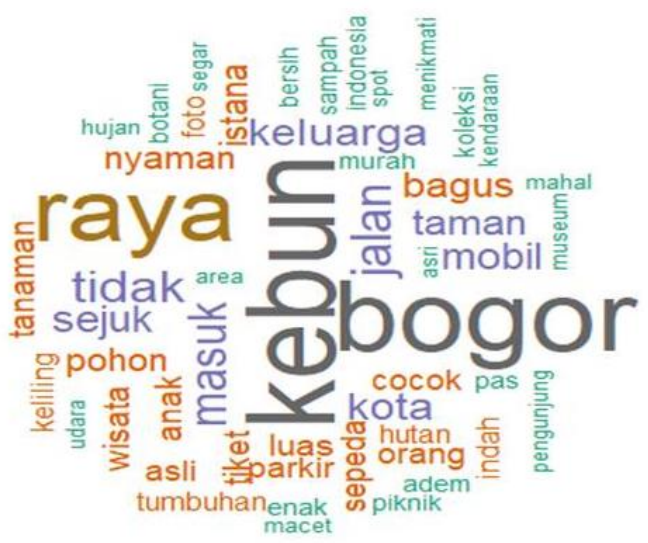

$4 \quad$ Frekuensi kata saat pandemi

Netral, 51

Sentimen negatif, 17

$5 \quad$ Visualisasi wordcloud saat pandemi
Sentimen positif, 201

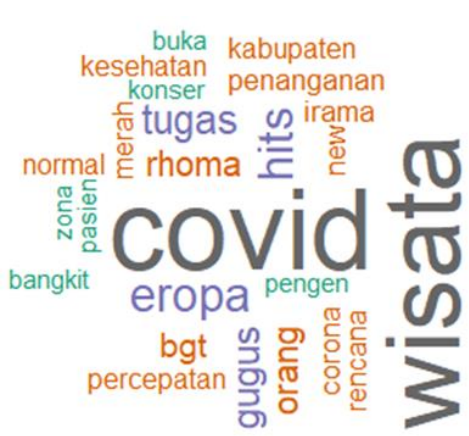

Sentimen positif, 1202

Netral, 94

Sentimen negatif, 62

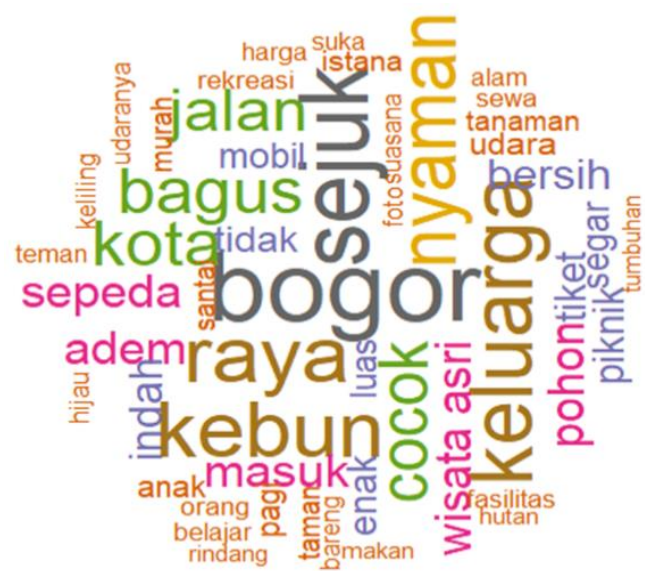


Tabel 2. Kategorisasi pernyataan hasil analisis sosial media

\begin{tabular}{|c|c|c|c|}
\hline A. Interaksi Sosial & $\begin{array}{l}\text { B. Kenyamanan } \\
\text { Abiotik }\end{array}$ & $\begin{array}{l}\text { C. Kepuasan terhadap } \\
\text { Layanan }\end{array}$ & $\begin{array}{l}\text { D. Isu dan Harapan } \\
\text { saat AKB }\end{array}$ \\
\hline $\begin{array}{l}\text { 1. Pilihan wisata } \\
\text { untuk } \\
\text { berjalan-jalan } \\
\text { bersama keluarga }\end{array}$ & 1. KRB luas & 1. KRB nyaman & 1. Kemacetan di Kota Bogor \\
\hline \multirow{6}{*}{$\begin{array}{l}\text { 2. Pengunjung } \\
\text { mengelilingi KRB } \\
\text { dengan mobil } \\
\text { bersama anak }\end{array}$} & $\begin{array}{l}\text { 2. Dekat dengan } \\
\text { istana Bogor }\end{array}$ & 2. Bagus pemandangannya & $\begin{array}{l}\text { 2. Harga makanan di dalam } \\
\text { KRB yang mahal }\end{array}$ \\
\hline & $\begin{array}{l}\text { 3. Hutan yang } \\
\text { didalamnya } \\
\text { terdapat koleksi } \\
\text { tumbuhan } \\
\text { dan pepohonan }\end{array}$ & $\begin{array}{l}\text { 3. Ketidakpuasan terhadap } \\
\text { tempat, harga, dan } \\
\text { kapasitas lahan parkir } \\
\text { kendaraan }\end{array}$ & $\begin{array}{l}\text { 3. Harga sewa sepeda yang } \\
\text { mahal }\end{array}$ \\
\hline & $\begin{array}{l}\text { 4. Akses jalan menuju } \\
\text { KRB bagus karena } \\
\text { dapat ditempuh } \\
\text { dengan mobil }\end{array}$ & $\begin{array}{l}\text { 4. Manajemen } \\
\text { pengelolaan } \\
\text { KRB profesional }\end{array}$ & $\begin{array}{l}\text { 4. Pencegahan penyebaran } \\
\text { COVID-19 di KRB dan } \\
\text { sekitarnya }\end{array}$ \\
\hline & $\begin{array}{l}\text { 5. Tiket masuk KRB } \\
\text { digunakan agar } \\
\text { pohon didalamnya } \\
\text { terawat }\end{array}$ & & $\begin{array}{l}\text { 5. KRB dibuka kembali saat } \\
\text { new normal }\end{array}$ \\
\hline & $\begin{array}{l}\text { 6. Terbatasnya } \\
\text { fasilitas } \\
\text { publik di KRB }\end{array}$ & & $\begin{array}{l}\text { 6. KRB hits karena mirip } \\
\text { dengan tempat wisata di } \\
\text { benua Eropa }\end{array}$ \\
\hline & $\begin{array}{l}\text { 7. Lalu-lalang } \\
\text { kendaraan di dalam } \\
\text { KRB }\end{array}$ & & \\
\hline
\end{tabular}


Tabel 3. Karakteristik Pengunjung

\begin{tabular}{|c|c|c|}
\hline Kondisi Demografi & Jumlah & Persentase \\
\hline \multicolumn{3}{|l|}{ Jenis Kelamin } \\
\hline Pria & 109 & $46.6 \%$ \\
\hline Wanita & 125 & $53.4 \%$ \\
\hline \multicolumn{3}{|l|}{ Usia } \\
\hline $17-25$ & 224 & $95.7 \%$ \\
\hline $26-34$ & 6 & $2.6 \%$ \\
\hline $35-43$ & 2 & $0.9 \%$ \\
\hline $44-52$ & 2 & $0.9 \%$ \\
\hline \multicolumn{3}{|l|}{ Domisili } \\
\hline Kota Bogor & 109 & $46.6 \%$ \\
\hline Luar Kota Bogor & 125 & $53.4 \%$ \\
\hline \multicolumn{3}{|l|}{ Pekerjaan } \\
\hline Pelajar & 14 & $5.98 \%$ \\
\hline Mahasiswa & 191 & $81.62 \%$ \\
\hline Dosen & 2 & $0.85 \%$ \\
\hline Jurnalis & 2 & $0.85 \%$ \\
\hline Pengusaha & 10 & $4.27 \%$ \\
\hline Karyawan Swasta & 6 & $2.56 \%$ \\
\hline Karyawan PNS/ BUMN & 3 & $1.28 \%$ \\
\hline Ibu Rumah Tangga & 6 & $2.56 \%$ \\
\hline
\end{tabular}

Tabel 4. Aktivitas Pengunjung

\begin{tabular}{lll}
\hline Aktivitas & Jumlah responden & Persentase \\
\hline Aktivitas Fisik & & \\
1. Jogging/ Berlari/ Jalan santai & 24 & $10.1 \%$ \\
2. Bersepeda & 7 & $3.1 \%$ \\
Kesehatan Mental & & \\
1. Refreshing & 78 & $33.5 \%$ \\
2. Relaksasi & 51 & $21.9 \%$ \\
Interaksi Sosial & & \\
1. Nongkrong & 30 & $12.7 \%$ \\
2. Berkumpul dengan teman/ keluarga/ kolega & 23 & $9.8 \%$ \\
Lainnya & & \\
1. Belajar/ Meneliti & 8 & $2.8 \%$ \\
2. Mampir/ Sekedar lewat & 6 & $2.3 \%$ \\
3. Beribadah (ada masjid di KRB) & 4 & $2.2 \%$ \\
4. Menikmati hobi (fotografi, senam dsb) & 3 & $1.6 \%$ \\
\hline
\end{tabular}


Tabel 5. Pendapat dan saran dari survei responden

\begin{tabular}{rlrr}
\hline Urutan & Masukan dan saran perbaikan & Jumlah & Persentase \\
\hline 1 & Perlu tambahan fasilitas & 32 & $14.4 \%$ \\
2 & Pengelolaan sudah sesuai protokol COVID-19 & 26 & $11.7 \%$ \\
3 & Pengelolaan lebih baik daripada sebelumnya & 24 & $10.8 \%$ \\
4 & Sangat bagus & 22 & $9.9 \%$ \\
5 & Sarana dan prasarana terawat & 16 & $7.2 \%$ \\
5 & Kebersihan terjaga & 16 & $7.2 \%$ \\
6 & Menenangkan hati dan pikiran & 14 & $6.3 \%$ \\
7 & Pemandangan indah & 10 & $4.5 \%$ \\
7 & KRB harus tetap dilestarikan & 10 & $4.5 \%$ \\
7 & Edukasi dan koleksi flora & 10 & $4.5 \%$ \\
8 & Tempat wisata semua kalangan masyarakat & 8 & $3.6 \%$ \\
8 & Semoga harga tiket masuk lebih murah & 8 & $3.6 \%$ \\
8 & Ikon kota Bogor yang dekat istana Bogor & 8 & $3.6 \%$ \\
9 & Sosialisasi lebih masif & 6 & $2.7 \%$ \\
10 & Perbaikan sarana yang rusak & 4 & $1.8 \%$ \\
10 & Harga wahana keliling mahal & 4 & $1.8 \%$ \\
10 & KRB mudah diakses namun macet & 4 & $1.8 \%$ \\
\hline
\end{tabular}



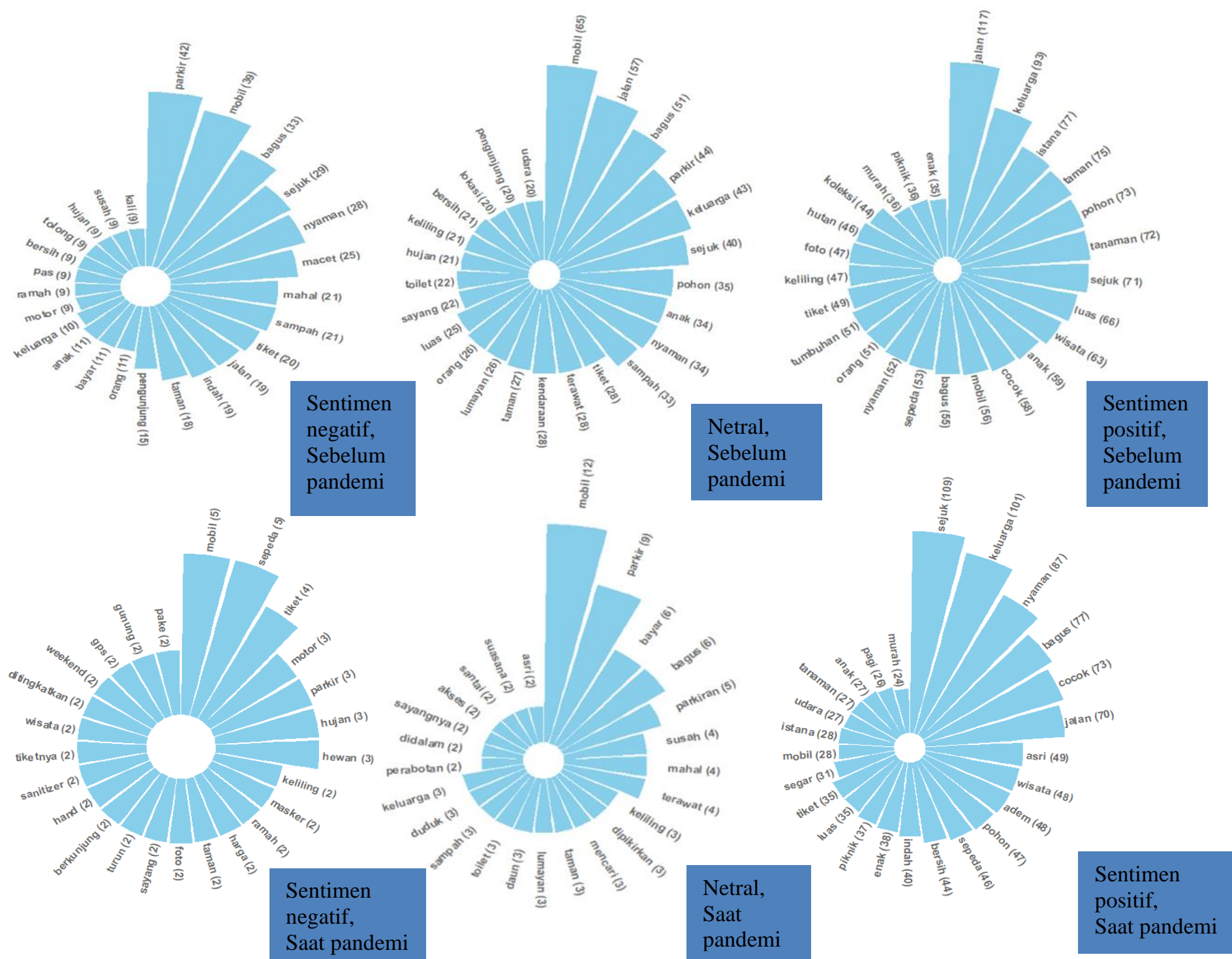

Gambar 1. Circlebar plot frekuensi kata hasil analisis Google Map Review 


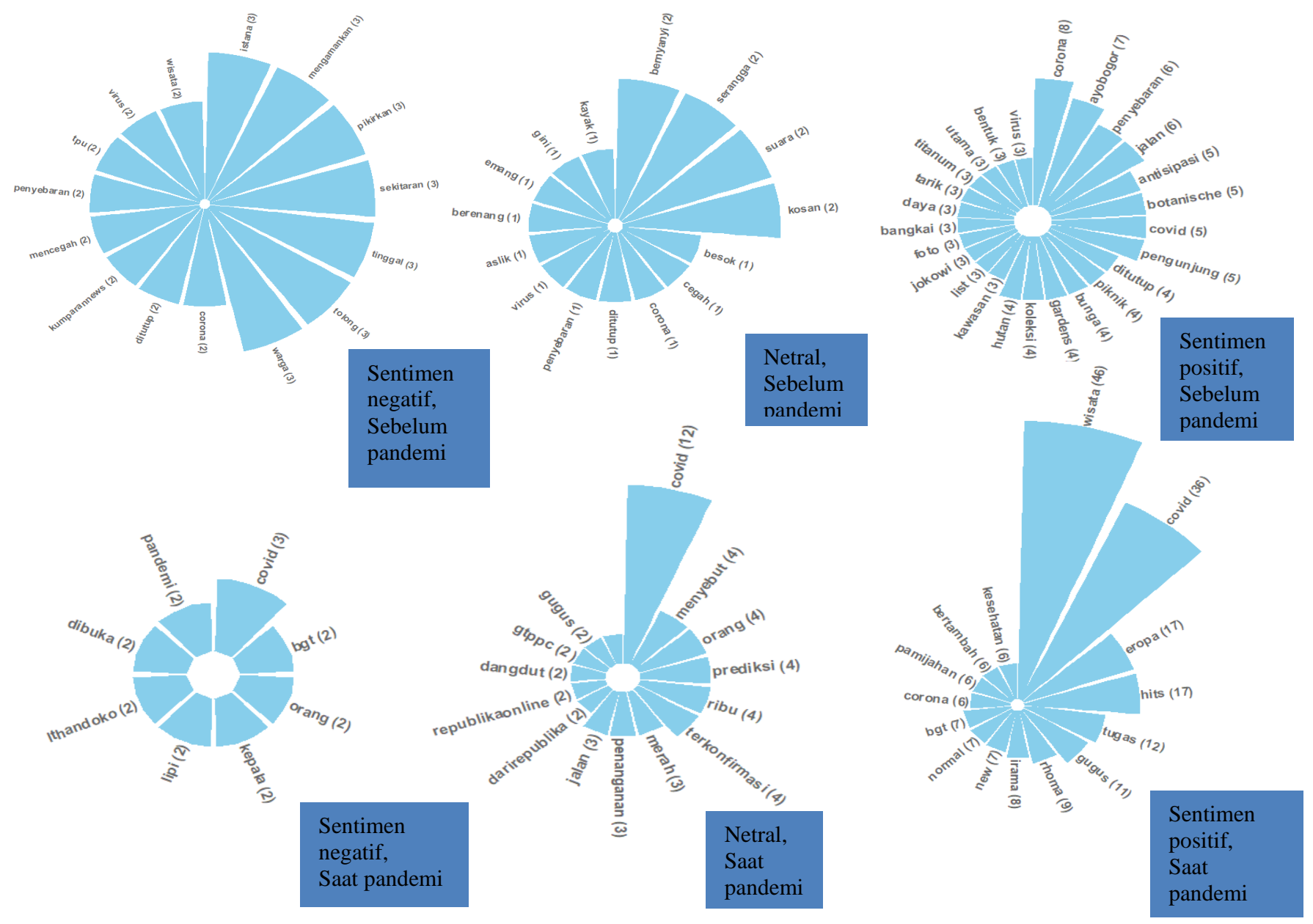

Gambar 2. Circlebar plot frekuensi kata hasil analisis Twitter 


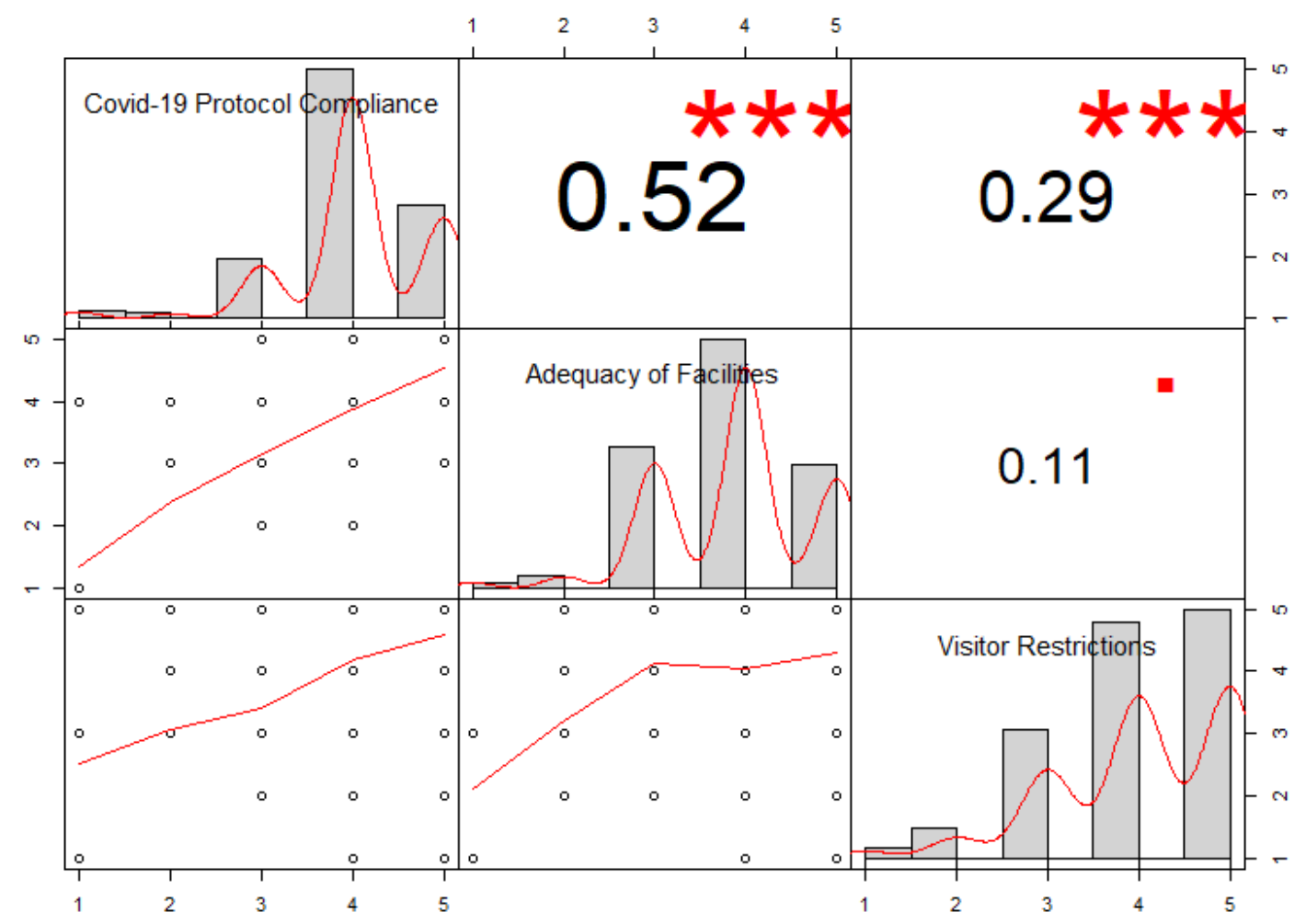

Gambar 3. Korelasi antar faktor; Covid-19 protocol compliance adalah kepatuhan terhadap protokol Covid-19, adequacy of facilities adalah fasilitas yang memadai dan visitor restrictions adalah pembatasan pengunjung

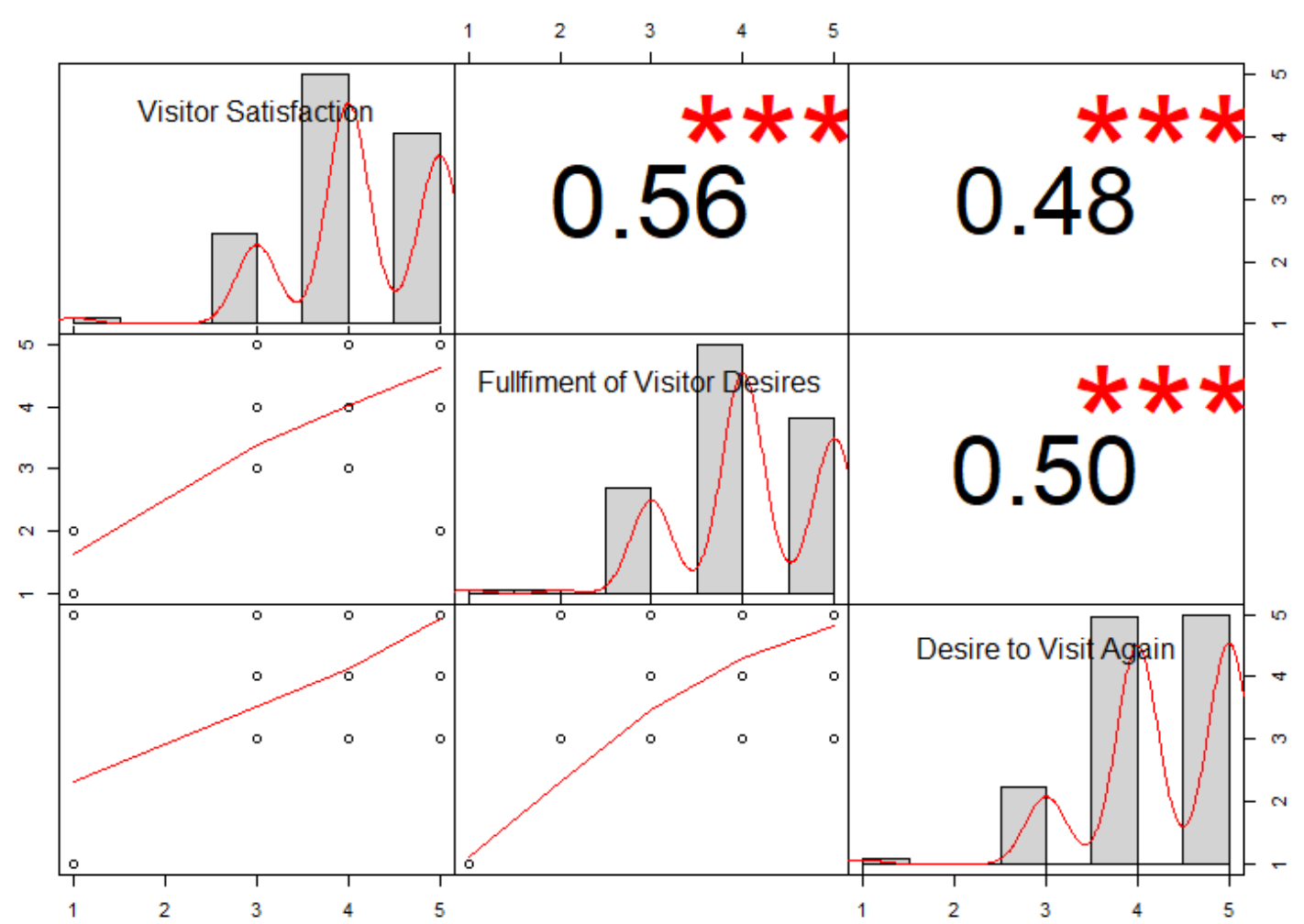

Gambar 4. Korelasi antar faktor; visitor satisfaction adalah kepuasan pengunjung, fulfillment of visitor desires adalah kepuasan pengunjung dan desire to visit again adalah keinginan pengunjung untuk kembali ke KRB 